\title{
Rusmiddelbruk og suicidal atferd
}

Ved Ingeborg R ossow

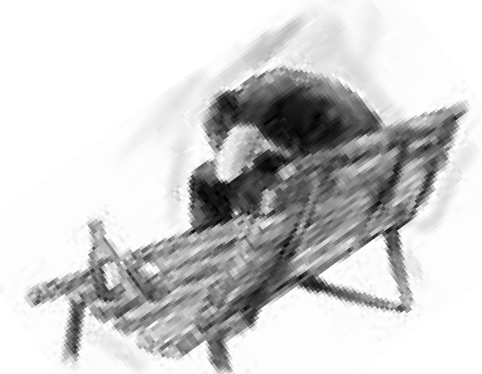

At det er en sammenheng mellom alkoholmisbruk og selvmord har vaert kjent lenge innenfor den psykiatriske litteraturen, siden de første studier fra tidlig på 1800-tallet viste at det var en høy forekomst av selumord blant alkoholmisbrukere.

Innenfor sosiologisk forskning har imidlertid denne sammenhengen vært nærmest neglisjert i tre kvart hundre år etter at Durkheim i boka "Selvmordet" (1897) forkastet en slik mulighet, både på teoretisk og empirisk grunnlag. Det er imidlertid særlig gjennom de siste 40 årene kommet til et betydelig omfang av epidemiologisk forskning som viser entydig en klar sammenheng mellom alkoholmisbruk og risiko for selvmord ( M urphy 2000). G jennom de siste par tiårene er det også gjort en rekke studier på sammenhenger mellom ulike aspekter ved alkoholkonsum (ikke bare misbruk) og suicidal atferd (både selvmord og selvmordsforsøk). Likeledes er det kommet til en rekke studier om tilsvarende sammenhenger mellom bruk av andre rusmidler en n alkohol og suicidal atferd.

Jeg vil i det følgende gi en sammenfatning av denne litteraturen, og deretter peke på noen mulige forklaringer på disse sammenhengene. Det er ingen tvil om at disse sammenhengene er komplekse, $0 \mathrm{~g}$ at det er flere mulige underliggende mekanismer som ligger til grunn for de sammenhengene vi kan observere i epidemiologiske studier. La meg derfor starte med noen historier fra virkeligheten ${ }^{1 .}$ H istoriene om "Tom", "Edna", "John" og "Ingrid" handler alle om rus og suicidal atferd, men på ulike måter.

\section{Noen eksempler}

"Tom" var 41 år da han døde av en overdose med barbiturater. $\mathrm{H}$ an hadde hatt en vanskelig oppvekst med en voldelig og alkoholisert far, mye skoleproblemer og skulking. $\mathrm{H}$ an begynte selv å drikke tett og mye fra 17-årsalderen. $\mathrm{H}$ an ble flere ganger arrestert for vold mot politiet i fylla og skiftet også jobb mange ganger, trolig på grunn av fyll. H an hadde sterke depressive symptomer i fylla, og flere selvmordsforsøk med barbiturater de siste 2-3 årene han levde. $\mathrm{H}$ an hadde giftet

${ }^{1}$ Tre av historiene er hentet fra kasuistikkbeskrivelser i internasjonale publikasjoner, og en historie er hentet fra et omfattende biografisk datasett i en norsk undersøkelse. seg tidlig, ekteskapet var stormfullt, og "Tom" ble skilt tre måneder før han døde. Det siste året "Tom" levde, drakk han enda mer enn før, og han ble gradvis mer sosialt isolert. En skuddskade i armen gjorde ham helt arbeidsufør de siste ti månedene han levde, og armen måtte amputeres ved albuen. Dette skulle ha skjedd uka etter at han døde. $\mathrm{H}$ an fortalte noen i familien at han skulle reise bort noen dager på fisketur før operasjonen, og ble derfor ikke savnet før det var gått en uke. $\mathrm{H}$ an ble funnet i huset sitt med gjenspikret dør, to tomme pilleglass (barbiturater) og tre avskjedsbrev.

"Edna" var 53 år da hun døde av en overdose antidepressiva. 0 gså hun hadde en alkoholisert far som var fraværende gjennom mesteparten av oppveksten, og en sterkt religiøs mor. $\mathrm{H}$ un giftet seg tidlig og hadde tre barn, som alle var flyttet hjemmefra da hun døde. H un hadde aldri arbeid utenfor hjemmet, og hadde få interesser. Gjennom sitt voksne liv ble hun gradvis mer introvert, genert, sårbar og trist til sinns, med økende opptatthet av sin egen mentale helse. De siste 14 årene hun levde, ble hun innlagt seks ganger i sykehus for alvorlig depresjon. H un følte seg engstelig, verdiløs, hadde skyldfølel se for sin medikamentbruk, gråt mye, var trett og tiltaksløs, og plaget av søvnløshet og vedvarende tanker om å ta sitt eget liv. $\mathrm{H}$ un ble gradvis mer folkesky, unngikk familien og familiens venner, og de siste 6-7 årene var hun omtrent bare sammen med ektemannen. G jennom mesteparten av sitt voksne liv drakk hun lite, men etter en periode med alvorlig depresjon begynte hun å drikke mye, og hun hadde et daglighøyt inntak av sprit i en treårsperiode. Deretter var hun avholdende i nesten fire år, men begynte så å drikke tett igjen den siste måneden før selvmordet. Da hun døde, var ektemannen bortreist i forretninger. $\mathrm{H}$ un hadde tømt diverse pillegl ass sammen med sprit, og lagt igjen et brev med instruksjoner for begravelsen.
"John" var 16 år da han skjøt seg i hodet. $\mathrm{H}$ an hadde en del problemer på skolen, og ble betegnet som en villstyring med stadige raseriutbrudd. Vennene mente han var umoden og usikker, og han hadde "misbrukt" alkohol og hasj i tre år før selvmordet. "John"s eldre bror misbrukte også alkohol og narkotika. Familien samlet på skytevåpen, og huset var, ifølge moren, det rene våpenlager. "John" skjøt seg med sitt eget våpen som han hadde fått av moren i gave. "John"s onkel hadde noen år tidligere tatt sitt eget liv, og dette var et hyppig samtaletema i familien. En annen onkel hadde skutt sin kone, og saken skulle snart opp til doms da "John" døde. En uke før selvmordet hadde "John" i en samtale med moren gitt en slags advarsel: M oren hadde engstet seg for at en annen gutt skulle gjøre ende på seg i en bilulykke eller med en overdose, og "John" sa: "Ta det rolig, mor, det blir ikke ham, det blir nok meg. " Dagen før selvmordet var "John" blitt utvist fra skolen på grunn av slåsskamp, og samme dag hadde han fyllekjørt med en venns bil og endt i grøfta. $\mathrm{H}$ an fikk hjelp av vennen til å få bilen opp, men sa da at han skulle drepe seg. Da han kom hjem den kvelden, gikk han rett ned på rommet sitt i kjelleren, og like etter hørte faren og broren skuddet. "John" hadde en promille på 1,7 da han døde.

"Ingrid" lever kanskje fremdeles. $\mathrm{H}$ un hadde en svært vanskelig oppvekst, hun ble seksuelt misbrukt av en mannlig slektning fra hun var fem år. I tillegg var faren alkoholisert og voldelig, og moren hadde store psykiske vansker. Foreldrene skilte seg, og "Ingrid" flyttet til noen slektninger. "Ingrid" ble mye mobbet som barn. H un begynte å sniffe lim og løsemidler da hun var 11, drakk seg full fra hun var 12 , og begynte så med hasj, og deretter heroin fra hun var 14. H un var 16 år da hun første gang kom til behandling for sitt stoffmisbruk. $\mathrm{H}$ un hadde da et omfattende blandingsmisbruk, var plaget av angst og depresjon, og hadde stadige selvmordstanker og klare planer om å ta sitt eget liv. I en alder av 16 hadde hun allerede gjort fire sel vmordsforsøk. 


\section{Sammenhengene i epidemiologiske studier}

Sammenhengene mellom rusmiddelbruk og suicidal atferd kan i hovedsak deles inn etter to tilnærminger; - hvor mye større er risikoen for at en rusmiddelmisbruker gjør selvmord eller selvmordsforsøk enn andre?, og - hvor stor andel av selvmordene og selvmordsforsøkene skyldes rusmiddel bruk?

\section{F orhøyet risiko for suicidal atferd blant rusmiddelmisbrukere}

$G$ rensene mellom hva som er bruk og hva som er misbruk av rusmidler er flytende, og de fleste studier av sel vmordsrisiko blant rusmiddelmisbrukere har tatt utgangspunkt i personer som har vært i behandling for sitt misbruk. Ved å følge opp en stor gruppe slike misbrukere over tid, kan man beregne dødeligheten ved selvmord i denne gruppen og sammenlikne dette med selvmordsdødeligheten i den generelle befolkningen innenfor samme kjønn og aldersgrupper. Dette forholdstallet omtales gjerne som standardi sert mortalitetsrate (SM R) eller relativ risiko.

\section{A lkohol:}

I norske studier har man funnet at alkoholmisbrukere har en selvmordsdødelighet som ligger omkring 5 til 7 ganger høyere enn i befolkningen som helhet. Dette svarer til hva man har funnet i de fleste tilsvarende studier fra andre land, hvor SM R stort sett har ligget et sted mellom 5 og 10 (altså 5-10 ganger så høy selvmordsrisiko blant alkoholmisbrukere som i befolkningen som helhet). Tidligere beregninger av hvor stor andel av alkoholmisbrukere som man kan forvente at vil dø ved selvmord lå på omkring 10-15\%, mens nyere tall basert på lange oppfølgingsstudier, indikerer at omkring 2-7\% av alkoholmisbrukere vil dø ved selvmord. N oen studier viser også at ikke bare misbrukere av alkohol, men også de som drikker relativt mye (og ikke minst drikker seg beruset relativt hyppig), har en høyere risiko for selvmord enn andre. 0 gså på aggregert nivå (tall for befolkninger $i$ et land, en stat eller region), finner vi at selvmordsratene ( særlig for menn) øker når alkoholkonsumet i befolkningen øker (Rossow 2000).

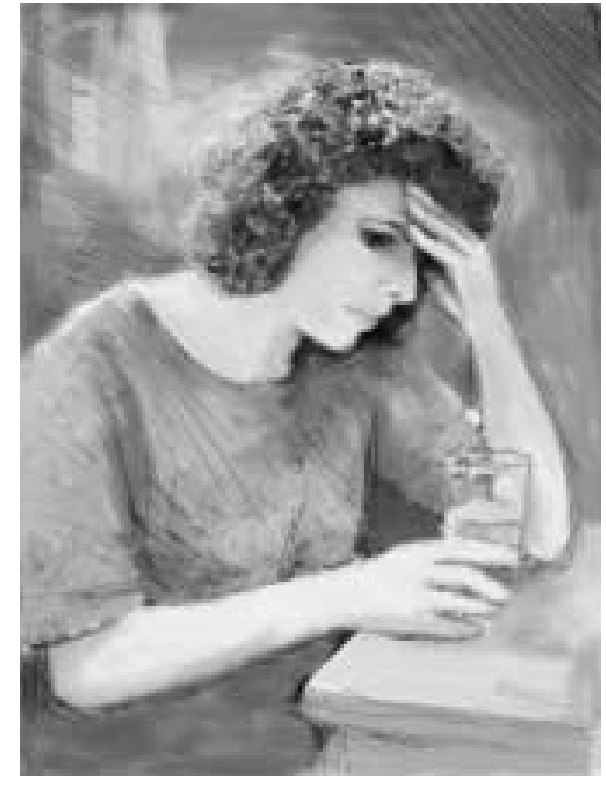

Sammenhengen mellom alkoholmisbruk og selvmordsforsøk er svakere dokumentert enn for fullbyrdete selvmord (Lester 1992), men flere studier har vist en vesentlig høyere forekomst av selvmordsforsøk blant alkoholmisbrukere enn blant andre. En studie av svenske menn viste også at sammenhengen mellom alkoholmisbruk og suicidal atferd er vesentlig sterkere med hensyn til selvmordsforsøk enn fullbyrdete sel vmord. A lkoholmisbrukere har omtrent 15 ganger høyere risiko for selvmordsforsøk enn befolkningen ellers, og vi antar at omkring hver 5. alkoholmisbruker har forsøkt å ta livet sitt minst én gang. Flere studier har også vist at det ikke bare er misbrukere som har en forhøyet risiko for selvmordsforsøk. I den vanlige befolkningen er risikoen for selvmordsforsøk høyere blant dem som har et relativt høyt alkoholkonsum og blant dem som ofte drikker seg beruset. (Rossow 2000).

\section{Narkotika:}

På samme måte som for alkoholmisbrukere, har også narkotikamisbrukere en betydelig høyere risiko for å ta sitt eget liv enn befolkningen for øvrig. O verdødeligheten for stoffmisbrukere ligger i størrel sesorden 20-30, dvs at stoffmisbrukere har en enda høyere dødelighet ved selvmord enn det alkoholmisbrukere har. Selvmord er også en av de vanligste dødsårsakene blant stoffmisbrukere, og vi regner at om lag en av 15 stoffmisbrukere dør ved selvmord før fylte 50 år. Selvmordsfor- søk er også svært utbredt blant stoffmisbrukere, og i overkant av hver tredje stoffmisbruker har forsøkt å ta sitt eget liv en eller flere ganger (R ossow \& Lauritzen 2001). O gså for dem som har en mer eksperimentell erfaring med narkotikabruk, ser vi at risikoen for selvmordsforsøk øker med bruken av illegale rusmidler.

\section{O mfang av suicidal atferd som kan tilskrives rusmiddelbruk}

Som vi har sett av det ovenstående, innebærer både alkoholmisbruk og narkotikamisbruk en betydelig forhøyet risiko for suicidal atferd. M en, hvor stor andel av selvmordene og selvmordsforsøkene kan vi tilskrive (eller si at "skyldes") rusmiddelbruk? En rekke studier har vist at andelen av alkoholmisbrukere er høy blant dem som tar sitt eget liv, og vi antar at omkring hvert 5. selvmord her i landet skyldes alkoholmisbruk. 0 gså blant dem som legges inn i sykehus med selvmordsforsøk er nærmere en tredjedel alkoholmisbrukere, og nærmere halvparten er beruset (på alkohol) . N arkotikabruk betyr rimeligvis mindre for omfanget av suicidal atferd, ettersom det er langt færre som bruker og misbruker narkotika sammenliknet med alkohol. Vi har ingen sikre tall, men antar at omkring 2-3\% av alle selvmord utgjøres av stoffmisbrukere, og tilsvarende omkring $5 \%$ av selvmordsforsøk med sykehusinnleggelse her i N orge. M urphy (2000) hevder at rusmiddelmisbrukere (alkohol og narkotika) utgjør 25-55 \% av alle selvmord, og at den økende narkotikabruken har spilt en vesentlig rolle for økningen av selvmord blant unge i U SA. Vi ser altså at beruselse og/ eller rusmiddelmisbruk er en vanlig "ingrediens" ved selvmord og selvmordsforsøk, men gir disse tallene et godt bilde av hvor stor andel av selvmordene og selvmordsforsøkene som "skyldes" rusmiddelbruk? Svaret kunne vært "ja" hvis to betingelser var oppfylt: - for det første at dersom det foreligger rusmiddelmisbruk eller berusel se, er dette alltid en (del-) årsak til den suicidale atferden, og - for det andre at bruk eller misbruk bare hadde betydning for brukeren selv. Ved å vurdere hvorvidt disse betingelsene er oppfylt, kommer vi også inn på hvilke underliggende mekanismer vi tenker oss for sammenhengene mellom rusmiddelbruk og suicidal atferd. 


\section{Underliggende mekanismer R usmiddelbruk som årsak til suicidal atferd}

Et langvarig rusmiddelmisbruk innebærer en betydelig økt sårbarhet for suicidal atferd på mange måter; - forringet psykisk helse (med angst og/eller depresjon), svakere sosial integrering, svekket selvbilde, økonomiske vanskeligheter og dystre framtidsperspektiver. En tilværelse

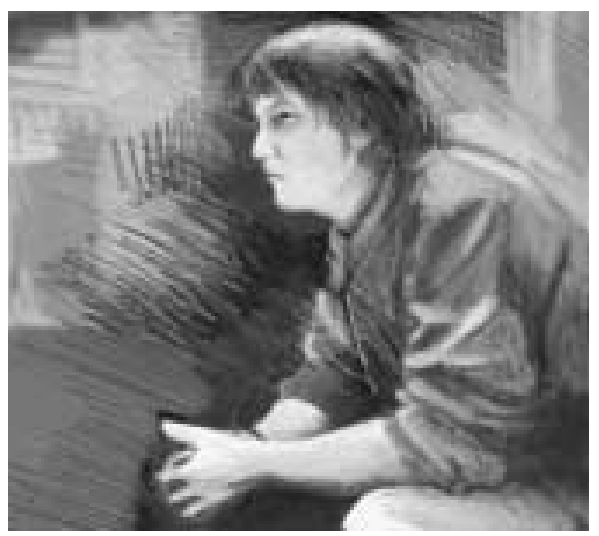

som rusmiddelmisbruker innebærer også at man oftere utsettes for utløsende hendelser som tap av partner, tap av arbeidsplass, og dype konflikter. $\mathrm{H}$ istorien om "Tom" kan være et godt eksempel på dette. Det er rimelig å anta at hans utvikling av depresjon var en følge av langvarig alkoholmisbruk; skilsmisse og tap av arbeidsplass var trolig også knyttet til misbruket hans, og den foreståen de amputasjonen av underarmen (som trolig var en utløsendefaktor) kan knyttestil en skuddskade i fylla.

0 gså akutt beruselse kan være en årsak til suicidal atferd ved at et depressivt stemningseie forsterkes, impulskontroll svekkes, og muligens at barrierer/motforestillinger mot å skade seg selv reduseres. H istorien om "John" kan tjene som et eksempel på dette. Det er riktignok også angitt at 16åringen "misbrukte" både alkohol og hasj, og det er uklart hva som ligger i dette, men det er neppe snakk om et misbruk av betydelig omfang og varighet. I "John"s tilfelle kan det ha vært en impulshandling i fylla, knyttet til flere nederlag/tap samme dag, men også fysisk tilgjengelighet av våpen og en bevissthet på selvmord som "Iøsning" gjennom onkelens selvmord har trolig også hatt betydning.

$M$ ange rusmiddel misbrukere bærer med seg en betydelig "bagasje" inn i utviklingen av sitt misbruk, f.eks. i form av primær depresjon eller personlighetsforstyrrelse, dårlig selvbilde, svake sosiale bånd, ustabil oppvekst osv. Fellesnevneren for mye av denne "bagasjen" er at den utgjør en betydelig sårbarhetsfaktor både i forhold til utvikling av rusmiddel misbruk og for selvpåførte skader. H istorien om "Ingrid"

handler om en ødel agt barndom og derigjennom en betydelig sårbarhet for selvmordsforsøk og selvmord. M ed en oppvekst som "Ingrid"s er sjansene for selvmordsforsøk og selvmord store allerede i utgangspunktet, og med et omfattende rusmiddelmisbruk, blir risikoen enda høyere. Rusmiddel bruken kan ha vært ment som en flukt fra - eller døyving av sårene fra overgrepene og ensomheten, men kan i stedet snarere ha forsterket depresjon, motløshet og dårlig selvbilde. "Ingrid"s bruk av narkotika kan derfor sees som en del av et komplekst bilde med mange sårbarhetsfaktorer som trolig henger sammen og forsterker betydningen av hverandre. O gså for "Edna"s del synes det å være en primær depresjon som ligger til grunn, og det er mulig at hennes periodiske al koholmisbruk har forsterket depresjonen, og derved i noen grad vært en medvirkende årsak. For alle disse fire historiene ser vi at rusmiddelbruken kan betraktes som en årsaksfaktor, men den synes i alle tilfellene å virke sammen med andre sårbarhetsfaktorer og utløsende faktorer. Bruk eller misbruk av rusmidler er derfor neppe i noen særlig utstrekning en tilstrekkelig årsak til suicidal atferd, og det vil være rimelig å anta at i en del tilfeller av selvmord og selvmordsforsøk har misbruk eller berusel se vært en ingrediens, men at årsakene har vært knyttet til andre forhold. Det er altså ikke gitt at alle selvmord eller selvmordsforsøk blant rusmiddel misbrukere skyldes misbruket. Det er mulig at "Edna" ville ha tatt sitt eget liv, også om hun ikke hadde hatt perioder med alkoholmisbruk, og det kan tenkes at "John" ville skutt seg selv også i edru tilstand.

Så til spørsmålet om rusmiddelbruk har betydning for suicidal atferd hos andre enn brukeren selv. Det finnes foreløpig få studier som har nærmet seg denne type sammenheng mellom rusmiddelbruk og suicidal atferd, men noen studier har vist at det blant barn av rusmiddelmisbrukere er en høyere andel som har forsøkt å ta sitt eget liv enn andre (se Rossow \&
Lauritzen 2001). Det er nærliggende å tenke seg at rusmiddelmisbruk også hos andre familiemedlemmer, f.eks. ektefelle, kan gi en økt sårbarhet for suicidal atferd. Spørsmålet om hvorvidt rusmiddel bruk bare har betydning for suicidal atferd hos brukeren selv, har klare paralleller for flere andre typer av rusmiddel relaterte skader. Ikke minst når det gjelder trafikkulykker

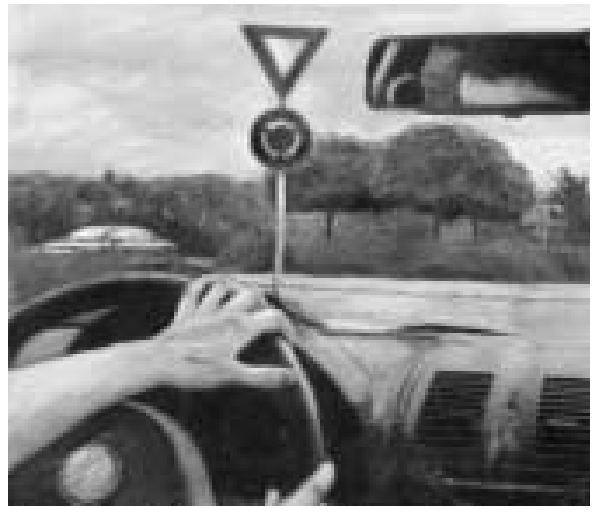

er det godt dokumentert at skadene ofte rammer en tredjepart, f.eks. passasjerer eller fotgjengere, og målsettingen om å begrense denne type skader på tredjepart er et særlig tungtveiende argument i den rusmiddel politiske debatten. En av mange viktige utfordringer $i$ den videre forskningen på dette feltet vil derfor være å få bedre belyst hvordan rusmiddelmisbruk kan ha betydning for suicidal atferd hos dem som står misbrukeren nær.

\section{Referanser}

Lester, D. A Icoholism and drug abuse. I: M aris, R.W., Berman, A .L., M altsberger, J.T., Yufit, R.I. (eds): A ssessment and prediction of suicide. N ew York: G uilford Press, 1992: 321-36

$M$ urphy, G.E. Psychiatric aspects of suicidal behaviour: Substance abuse. I: $\mathrm{H}$ awton, $\mathrm{K}$. van $\mathrm{H}$ eeringen, $\mathrm{K}$. (eds): $\mathrm{T}$ he international handbook of suicide and attempted suicide, C hichester: W iley, 2000: 136-46.

Rossow, I. Suicide, violence and child abuse: a review of the impact of alcohol consumption on social problems. Contemporary Drug Problems 2000; 27: 397- 433 .

Rossow, I., Lauritzen, G. Shattered childhood - a key issue in suicidal behavior among drug addicts? A ddiction 2001; 96: 227-240.

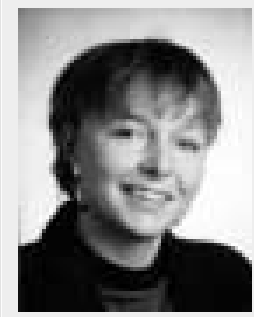

Ingeborg R ossow er forskningsleder ved N OVA, N orsk institutt for velferd, oppvekst og aldring. 